\title{
Isotopic tracing of groundwater at Žitný ostrov (SW Slovakia)
}

\author{
P. P. PovineC ${ }^{1 *}$, Z. Ženišová ${ }^{2}$, R. Breier ${ }^{1}$, \\ M. Richtáriková ${ }^{1}$ and A. ŠIvo ${ }^{1}$
}

${ }^{1}$ Comenius University, Faculty of Mathematics, Physics and Informatics, Department of Nuclear Physics and Biophysics - Mlynská dolina, 84215 Bratislava, Slovakia

2 Comenius University, Faculty of Natural Sciences, Department of Hydrogeology - Mlynská dolina, 84215 Bratislava, Slovakia

\begin{abstract}
Geostatistical analysis of experimental isotope data has been carried out with the aim to study spatial variations in the distribution of water isotopes and radiocarbon in groundwater of Žitný ostrov (Rye Island), which is the largest reservoir (about $10 \mathrm{Gm}^{3}$ ) of groundwater in the Central Europe. Subsurface water profiles showed enriched $\delta^{18} \mathrm{O}$ levels at around $20 \mathrm{~m}$ water depth and depleted values below $30 \mathrm{~m}$, which are similar to those observed in the Danube River. The core of the subsurface ${ }^{14} \mathrm{C}$ profile represents contemporary groundwater with ${ }^{14} \mathrm{C}$ values above $80 \mathrm{pMC}$.
\end{abstract}

\section{Introduction}

Stable and radioactive isotopes have been extensively used as environmental tracers during the last decades to study the water cycle, to better understand the origin, dynamics and interconnections of the different elements of the hydrologic cycle. It has been possible to study the present day distribution

*E-mail: povinec@fmph.uniba.sk.

This is an Open Access article distributed under the terms of the Creative Commons Attribution License 2.0, which permits unrestricted use, distribution, and reproduction in any medium, provided the original work is properly cited. 
of water isotopes in the atmosphere, in the rain water, river water, groundwater, and then trace past isotopic compositions affecting many processes, such as atmospheric circulation, rain and snow formation, groundwater formation, ecology and paleoclimatology [1]. Radioactive and stable isotopes have been used to address key aspects of the water cycle, e.g. the origin, dynamics and interconnections of the different elements of the water cycle $[2,3]$. Fortunately with the development of the IAEA's Global Network of Isotopes in Precipitation (GNIP) database it has been possible to use isotopes in hydrological, ecological and climate studies, as input functions have been available for many areas of the world [4]. Many isotope data have been collected and several isotope databases have been developed. The GNIP database (www.GNIP.IAEA.org) has provided key data for the application of isotopes in hydrology, but also in climatic and ecological studies. Recently this monitoring activity has been enlarged to isotopes in the total water cycle, and the new isotope database (Isotope Hydrology Information System (ISOHIS), www.ISOHIS.IAEA.org), also covering groundwater data, together with the GNIP database enables to study dynamics and spatial characteristics of groundwater.

It is possible to trace the origin and pathways of different water masses on the bases of the developed isotopic maps, covering temporal and spatial distribution of hydrochemical and isotope data. Recently new geostatistical tools have been developed to integrate isotope data into a relational database covering also hydrogeology and hydrochemistry, which using GIS would be possible to visualize, and in this way to create temporal-spatial isotope maps of groundwater $[5,6]$. Such an integrated attempt will gather new information on temporal and spatial variability of groundwater, on its dynamics, on anthropogenic and climatic impacts, and on its vulnerability. From the existing and new $\delta^{2} \mathrm{H}-\delta^{18} \mathrm{O}$ data obtained in the framework of the project, as well as from other data on isotopic composition and trace elements in groundwater, using results from Slovak institutions it will be possible to produce isotope maps of groundwater of Slovakia, and after their analysis to gather new information on groundwater.

Stable isotopes [7] and radiocarbon [8-10] have been applied in a few groundwater studies in Slovakia, however, there has not been done yet an integrated research, which would cover in full complexity all Slovakia (Fig. 1), not to speak that such a research should also cover the Central European countries. Some previous isotope hydrology work in Slovakia, e.g. on mineral and thermal waters [8] contributed to understanding of origin of these waters, however, temporal and spatial information has been missing, which could better characterize specific groundwater localities, groundwater 


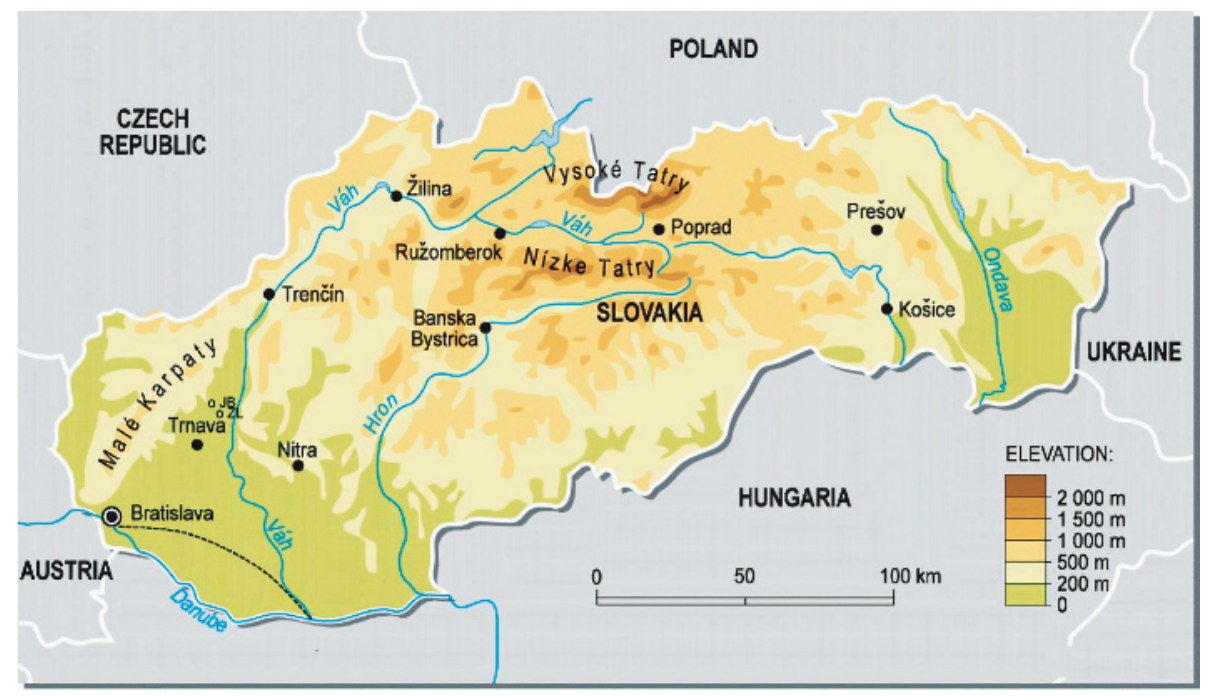

Fig. 1: The map of Slovakia with topography and the main river system. The Žitný ostrov is bordered by the Danube River on the south, and the Malý Dunaj (Small Danube) on the north (dashed line).

ages, infiltration areas, recharging characteristics of groundwater reservoirs, a danger of their contamination, climatic changes, etc., all important facts for the protection and correct exploitation of groundwater from the longterm perspective.

In this paper we report results on the spatial radiocarbon and stable isotope $\left({ }^{18} \mathrm{O}\right.$ and $\left.{ }^{13} \mathrm{C}\right)$ variability of groundwater found at the Žitný ostrov, SW Slovakia.

\section{Hydrogeology background}

The Žitný ostrov with the area of $1200 \mathrm{~km}^{2}$ covers the territory of the Danube Plane from Bratislava at NW to Komárno at SE (Fig. 1). It is bordered on the north by the river Small Danube, and on the east by the river Váh. The territory of the Žitný ostrov is of great economical significance as it represents the largest reservoir of groundwater in the Central Europe (about $10^{10} \mathrm{~m}^{3}$, what represents potential $\sim 18 \mathrm{~m}^{3} \mathrm{~s}^{-1}$ ). In 1987 the territory of the Žitný ostrov was declared as the National protected water resources territory of Slovakia. There are several groundwater sources situated at the territory of the Žitný ostrov, which are delivering drinking water to Bratislava as well as to many other places of the south western Slovakia. 


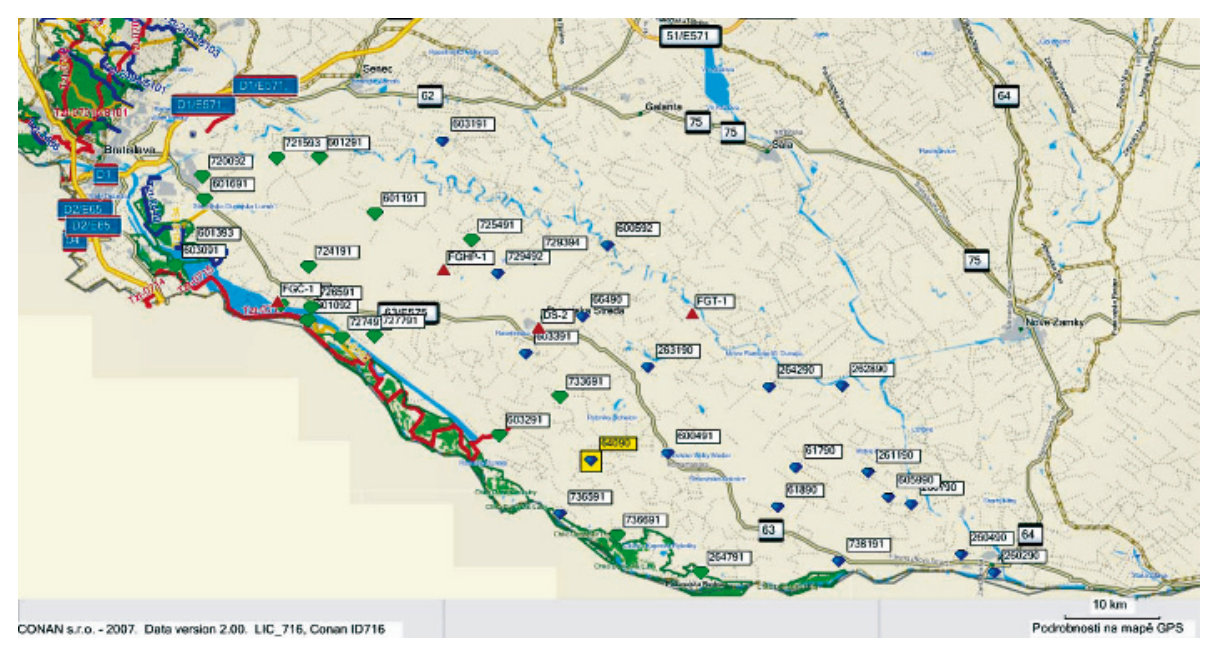

Fig. 2: Sampling sites of groundwater in the SW Slovakia.

The Žitný ostrov territory has also important a social value with several protected regional areas. The Žitný ostrov is also because of its location and good soil and climatic conditions the most important agricultural region of Slovakia. There is also located the most important Slovak water power plant, called Gabčíkovo (established in 1992), which is producing $720 \mathrm{MW}$ of electricity, and considerable influenced the Danube river shipping conditions. Due to the back water effect, the level of groundwater in the region of Bratislava has increased by about $2 \mathrm{~m}$, what have had important positive impact on all ecosystems in the region. From the geomorphology point of view, the Žitný ostrov belongs to the Danube Plain. The territory represents a flat terrain with $136-129 \mathrm{~m}$ above sea level. The average precipitation during 1951-1980 was in Bratislava $580 \mathrm{~mm}$. The average evaporation from the soil surface at the Žitný ostrov for the time interval between 1961 and 1990 was 450-500 mm. A total potential evaporation was between 700 and $800 \mathrm{~mm}$.

The Danube River during all its water levels in the Žitný ostrov feeds groundwater in the region. A general trend in the flow of groundwater is mostly following the main rivers in the region (Danube, Malý Dunaj and Váh). Precipitation is influencing groundwater regime especially during summer, in connection with elevated flow rates in rivers, and also by increasing the groundwater level (with different delay depending on the distance from the river). The described sites are shown in Fig. 2. 


\section{Samples and analytical methods}

The sampling sites were identical with groundwater sources regularly monitored by the Slovak Hydrometeorological Institute in the south-western Slovakia (Fig. 2). Sampling campaigns were carried out in November 2008 and in June 2009, visiting 38 boreholes. Groundwater samples were taken from deepest horizons. Description of the wells is presented in table 1. The sampling of water from boreholes was carried out in such a way that inflows were isolated from their overlying and/or underlying strata. All pipes of each borehole are cemented above perforation, so the wells are technically prevented from inflows of waters into the borehole from its sealed part. This, however, cannot prevent mixing of waters during their flow in aquifers. Such cases can occur especially in discharge areas, when waters of deep flow may be influenced by a shallow groundwater. During groundwater sampling in situ measurements of basic physical and chemical parameters (groundwater temperature, air temperature, $\mathrm{pH}$, electrical conductivity (EC), oxidationreduction potential (Eh), concentration of dissolved oxygen, and oxygen saturation) were carried out as well. Water samples for radiocarbon analysis of $\sim 50 \mathrm{l}$ volume were collected directly from the source. Bicarbonates were extracted as soon as possible by precipitation with barium chloride. Produced $\mathrm{BaCO}_{3}$ was stored in polyethylene containers and transported to the laboratory. Simultaneously small volume water samples (11) were collected for analysis of tritium and stable isotopes. Table 1 describes the sampling sites as well as the shallow wells.

Laboratory analyses included: analysis of stable isotopes $\left({ }^{18} \mathrm{O},{ }^{13} \mathrm{C}\right)$, preparation of gas fillings and ${ }^{14} \mathrm{C}$ activity measurement. A few $\mathrm{ml}$ of carbon dioxide liberated from the $\mathrm{BaCO}_{3}$ sample used for the determination of the isotopic ratio of ${ }^{13} \mathrm{C} /{ }^{12} \mathrm{C} . \delta^{13} \mathrm{C}$ values are expressed relative to the VPDB standard (in \%o). ${ }^{18} \mathrm{O} /{ }^{16} \mathrm{O}$ isotopic ratio was analyzed directly in water samples [11], and the $\delta^{18} \mathrm{O}$ data are reported relative to VSMOW (in \%o). Relative uncertainties were below $0.2 \%$ (at $1 \sigma$ ). For ${ }^{14} \mathrm{C}$ analysis carbon dioxide was released from barium carbonate by addition of $\mathrm{H}_{3} \mathrm{PO}_{4}$. Methane [12] synthesized from carbon dioxide was used as a filling gas of the low-level proportional counter [13]. Measuring time of samples was from forty to sixty hours. In addition to each water sample, samples of background and of radiocarbon standard (NIST Oxalic Acid) were also measured. ${ }^{14} \mathrm{C}$ results are expressed as percent modern carbon (pMC) relative to the NIST (National Institute of Standards and Technology, Gaithersburg, USA) ${ }^{14} \mathrm{C}$ standard. All ${ }^{14} \mathrm{C}$ data were corrected for $\delta^{13} \mathrm{C}$. Relative uncertainties were below $10 \%$ (at $1 \sigma$ ). Department of Nuclear Physics of the Faculty of Mathematics, 
Table 1: Groundwater sampling sites at the Žitný ostrov.

\begin{tabular}{|c|c|c|c|c|}
\hline $\begin{array}{l}\text { St. } \\
\text { n. }\end{array}$ & Locality & $\begin{array}{c}\text { Proge } \\
\text { depth } \\
(\mathrm{m})\end{array}$ & $\begin{array}{c}\text { Sampling } \\
\text { year }\end{array}$ & GPS position \\
\hline 1 & VLKY & 30.48 & 2008 & N48 0850.0 E17 2126.0 \\
\hline 2 & MALINOVO & 54.66 & 2008 & N48 0847.7 E17 1830.7 \\
\hline 3 & VYDRANY - KVETOSLAVOV & 72.70 & 2008 & N48 0239.9 E17 2042.0 \\
\hline 4 & ŠAMORÍN - ČILISTOV & 88.46 & 2008 & N48 0029.9 E17 1847.0 \\
\hline 5 & ROHOVCE - ŠTRKOVEC & 83.28 & 2008 & N47 5844.3 E17 2514.4 \\
\hline 6 & KALINKOVO & 57.06 & 2008 & N48 0342.4 E17 1231.6 \\
\hline 7 & OL'DZA & 67.33 & 2008 & N48 0539.8 E17 2516.2 \\
\hline 8 & ŠAMORÍN - MLIEČNO & 69.92 & 2008 & N48 0020.1 E17 2053.1 \\
\hline 9 & VRAKÚŇ & 78.50 & 2008 & N47 5518.2 E17 3800.6 \\
\hline 10 & DOBROHOŠŤ & 80.50 & 2008 & N47 5935.6 E17 2038.2 \\
\hline 11 & VOJKA & 30.64 & 2008 & N47 5839.1 E17 2257.5 \\
\hline 12 & GABČÍKOVO & 25.14 & 2008 & N47 5308.0 E17 3349.6 \\
\hline 13 & KL'ÚČOVEC & 50.33 & 2008 & N47 4728.3 E17 4156.8 \\
\hline 14 & KLIŽSKÁ NEMÁ & 26.90 & 2008 & N47 4522.5 E17 4743.0 \\
\hline 15 & HORNÁ POTÔŇ & 35.78 & 2008 & N48 0409.5 E17 3154.7 \\
\hline 16 & ČUŇOVO & 66.91 & 2008 & N48 0242.8 E17 1132.0 \\
\hline 17 & ROVINKA & 62.26 & 2008 & N48 0628.2 E17 1331.3 \\
\hline 18 & PODUNAJSKÉ BISKUPICE & 23.65 & 2008 & N48 0746.1 E17 1322.8 \\
\hline 19 & VEL'KÝ MEDER & 35.14 & 2009 & N47 5207.2 E17 4530.2 \\
\hline 20 & MLIEČANY & 24.24 & 2009 & N47 5744.1 E17 3540.3 \\
\hline 21 & VEL'KÉ BLAHOVO & 28.71 & 2009 & N48 0303.5 E17 3617.2 \\
\hline 22 & ORECHOVÁ POTÔŇ & 20.80 & 2009 & N48 0215.8 E17 3343.8 \\
\hline 23 & SAP & 46.45 & 2009 & N47 4840.5 E17 3800.4 \\
\hline 24 & ČALOVEC KAMENIČNÁ & 10.89 & 2009 & N47 4936.5 E18 0038.5 \\
\hline 25 & KAMENIČNÁ PIESKY & 15.22 & 2009 & N47 5101.3 E17 5914.8 \\
\hline 26 & OKOČ-ASZÓD & 15.53 & 2009 & N47 5550.4 E17 5225.6 \\
\hline 27 & JAHODNÁ & 34.92 & 2009 & N48 0351.1 E17 4117.2 \\
\hline 28 & JELKA & 25.42 & 2009 & N48 0945.9 E17 2955.4 \\
\hline 29 & KOMÁRNO & 9.75 & 2009 & N47 4622.1 E18 0539.7 \\
\hline 30 & KOMÁRNO & 7.91 & 2009 & N47 4520.9 E18 0756.0 \\
\hline 31 & ZLATNÁ N. OSTROVE & 15.60 & 2009 & N47 4559.8 E17 5712.9 \\
\hline 32 & KAMENIČNÁ & 7.93 & 2009 & N47 4912.2 E18 0213.2 \\
\hline 33 & DVORNÍKY N. OSTROVE & 8.90 & 2009 & N47 5949.4 E17 3934.6 \\
\hline 34 & HORNÝ ŠTÁL-ŽELEZ. STANICA & 11.01 & 2009 & N47 5657.8 E17 4404.1 \\
\hline 35 & PATAŠ MILINOVICE & 7.80 & 2009 & N47 5142.1 E17 4008.8 \\
\hline 36 & ZEMIANSKA OLČA & 6.32 & 2009 & N47 4903.8 E17 5300.9 \\
\hline 37 & ZEMIANSKA OLČA & 6.01 & 2009 & N47 5117.3 E17 5415.9 \\
\hline 38 & KOLÁROVO & 8.98 & 2009 & N47 5553.6 E17 5727.4 \\
\hline
\end{tabular}


Table 2: Stable isotope and radiocarbon data.

\begin{tabular}{|c|c|c|c|c|}
\hline St. n. & Locality & $\delta^{18} \mathrm{O}$ & $\delta^{13} \mathrm{C}$ & ${ }^{14} \mathrm{C}$ \\
\hline & & $(\%)$ & $(\%)$ & $\mathrm{pMC}$ \\
\hline 1 & Vlky & -10.553 & -15.406 & 89.62 \\
\hline 2 & Malinovo & -10.954 & -15.406 & 93.47 \\
\hline 3 & Vydrany-Kvetoslavov & -10.941 & -12.786 & 82.63 \\
\hline 4 & Šamorín-Čilistov & -10.863 & -15.201 & 97.17 \\
\hline 5 & Rohovce-Štrkovec & -10.657 & -15.557 & 80.44 \\
\hline 6 & Kalinkovo & -10.618 & -15.165 & 105.51 \\
\hline 7 & Ol'dza & -10.825 & -16.810 & 91.24 \\
\hline 8 & Šamorín- Mliečno & -10.702 & -14.793 & 76.47 \\
\hline 9 & Vrakuň & -11.119 & -13.510 & 97.11 \\
\hline 10 & Dobrohošt' & -10.8 & -10.656 & 78.88 \\
\hline 11 & Vojka & -10.669 & -15.738 & 98.69 \\
\hline 12 & Gabčíkovo & -10.893 & -14.911 & 92.41 \\
\hline 13 & Kl'účovec & -10.917 & -11.728 & 86.48 \\
\hline 14 & Kližská Nemá & -10.275 & -17.529 & 43.81 \\
\hline 15 & Horná Potôñ & -10.585 & -14.393 & 82.52 \\
\hline 16 & Čunovo & -10.548 & -19.224 & 84.81 \\
\hline 17 & Rovinka & -11.018 & -13.060 & 90.76 \\
\hline 18 & $\begin{array}{l}\text { Pod. Biskupice - N. } \\
\text { Košariská }\end{array}$ & -10.82 & -15.244 & 72.86 \\
\hline 19 & Komárno & -10.584 & -15.849 & 86.83 \\
\hline 20 & Komárno & -10.094 & -14.134 & 80.22 \\
\hline 21 & Čalovec - Kameničná & -12.219 & -11.080 & 31.54 \\
\hline 22 & Kameničná & -9.102 & -15.859 & 90.05 \\
\hline 23 & Zlatná na Ostrove & -11.041 & -11.485 & 72.92 \\
\hline 24 & Zemianska Olča & -10.273 & -12.150 & 93.59 \\
\hline 25 & Zemianska Olča & -9.279 & -12.541 & 86.62 \\
\hline 26 & Kameničná - Piesky & -10.276 & -12.044 & 69.86 \\
\hline 27 & Kolárovo & -10.927 & -13.933 & 99.58 \\
\hline 28 & Okoč - Aszód & -10.423 & -12.623 & 81.16 \\
\hline 29 & Sap & -11.034 & -10.791 & 90.36 \\
\hline 30 & Paraš - Malinovice & -10.712 & -11.600 & 82.24 \\
\hline 31 & Čalovo - Vel'ký Meder & -11.056 & -10.621 & 63.02 \\
\hline 32 & Horný Štál - žel.stanica & -10.659 & -12.053 & 89.62 \\
\hline 33 & Mliečany & -11.312 & -11.502 & 83.95 \\
\hline 34 & Dvorníky na Ostrove & -10.612 & -12.692 & 93.85 \\
\hline 35 & Jahodná & -11.148 & -11.425 & 80.80 \\
\hline 36 & Vel'ké Blahovo & -10.46 & -12.664 & 89.41 \\
\hline 37 & Orechová Potoň & -10.916 & -11.608 & 84.99 \\
\hline 38 & Jelka & -10.727 & -12.986 & 79.49 \\
\hline
\end{tabular}




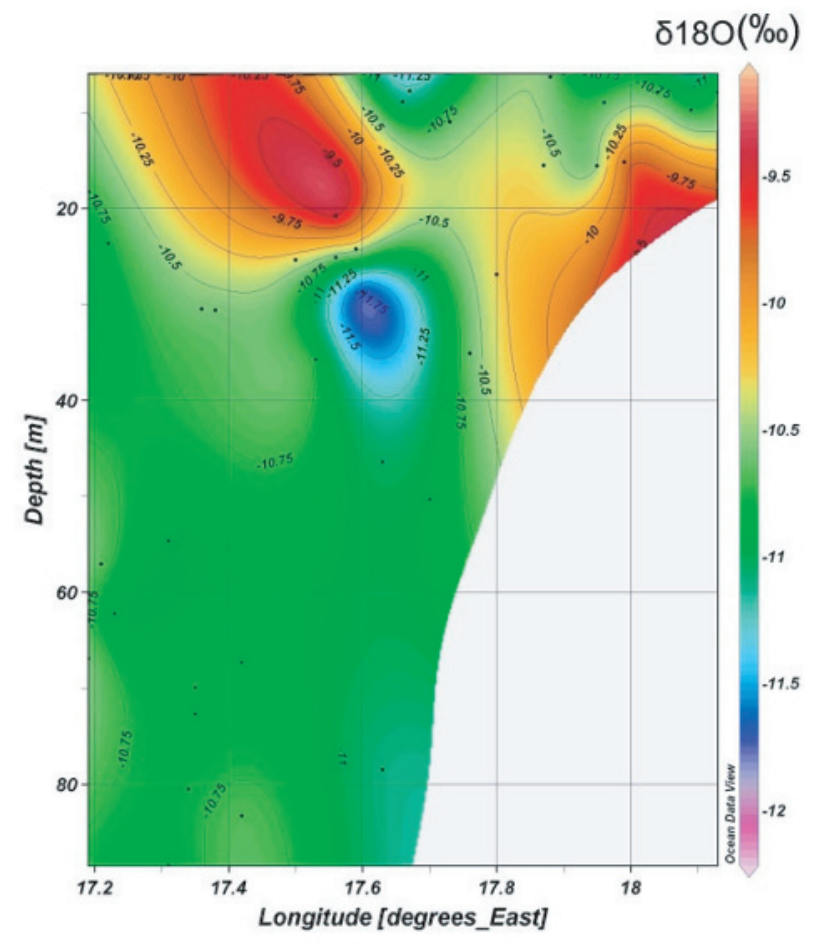

Fig. 3: Vertical distribution of $\delta^{18} \mathrm{O}$ (in \%) with longitude in groundwater of Žitný ostrov.

Physics and Informatics of the Comenius University in Bratislava has over 40 years of experience in radiocarbon measurements [14]. Quality management of all analyses has been assured by analysis of reference materials, and by participation in intercomparison exercises.

\section{Results and discussion}

The position of sampling sites and isotope data are presented in table 1 and 2 , respectively. The spatial distribution of $\delta^{18} \mathrm{O}$ in surface and subsurface waters with longitude of the Žitný ostrov area is presented in Fig. 3. While the bottom samples are depleted in $\delta^{18} \mathrm{O}$ values, generally below $-10.5 \%$, similar to the Danube values, the subsurface core observed at around $20 \mathrm{~m}$ water depth shows enriched $\delta^{18} \mathrm{O}$ values between $-10.0 \%$ and $-9.5 \%$. However, the surface samples (up to $10 \mathrm{~m}$ water depth) show again depleted $\delta^{18} \mathrm{O}$ values, close to the values observed for the Danube river 


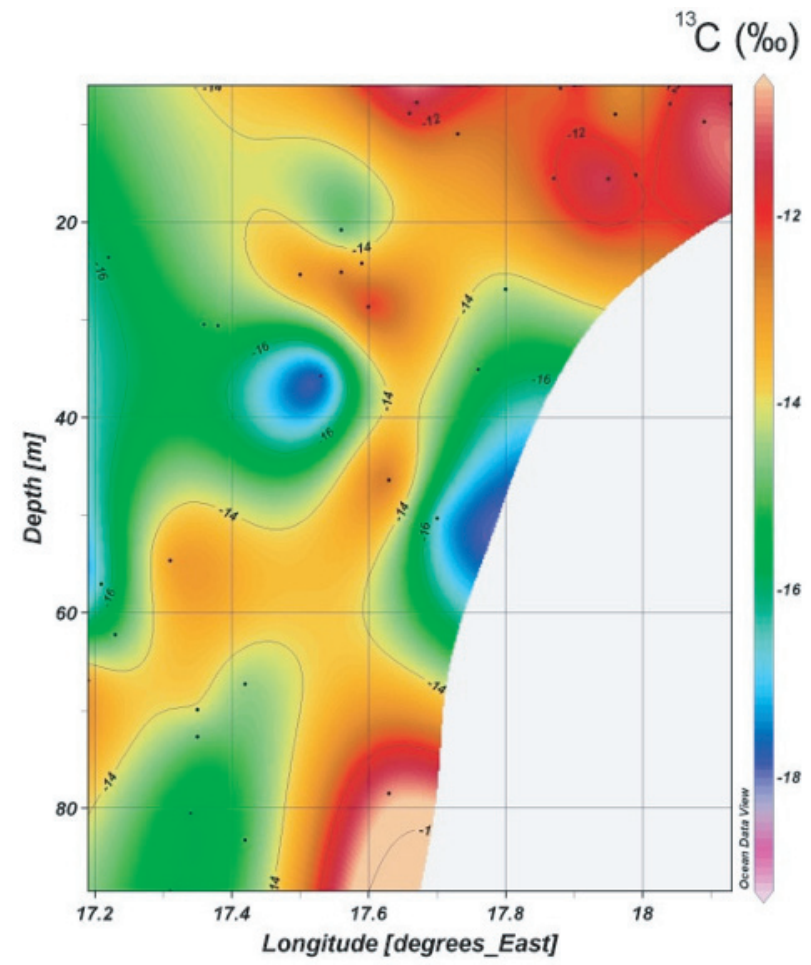

Fig. 4: Vertical distribution of $\delta^{13} \mathrm{C}$ (in \%o) with longitude in groundwater of Žitný ostrov.

system. The obtained data are in good agreement with isotope data measured the for Danube river system (values between $-10.92 \%$ and $-12.26 \%$ for Danube, and between $-0.57 \%$ and $-11.39 \%$ for Malý Dunaj). As expected, the Danube river system is the main source of shallow groundwater observed at Žitný ostrov. It is possible that surface and shallow subsurface waters showing enriched $\delta^{18} \mathrm{O}$ values may be due to land irrigation, which has been often used in this agriculturally heavily industrialized region. Fig. 4 also shows a similar profile for $\delta^{13} \mathrm{C}$. Here we see enriched $\delta^{13} \mathrm{O}$ levels in surface waters, and a depleted layer at water depths around $40 \mathrm{~m}$. From the subsurface radiocarbon profile with longitude also shown in Fig. 3 we can see a subsurface core of about $50 \mathrm{pMC}$ at around $60 \mathrm{~m}$ water depth, while the surface samples up to $10 \mathrm{~m}$ water depth show ${ }^{14} \mathrm{C}$ values above $80 \mathrm{pMC}$, representing contemporary groundwater (Fig. 5).

This has been a first attempt to construct isotope maps and to study surface and subsurface distribution of isotopes in groundwater of Slovakia. 


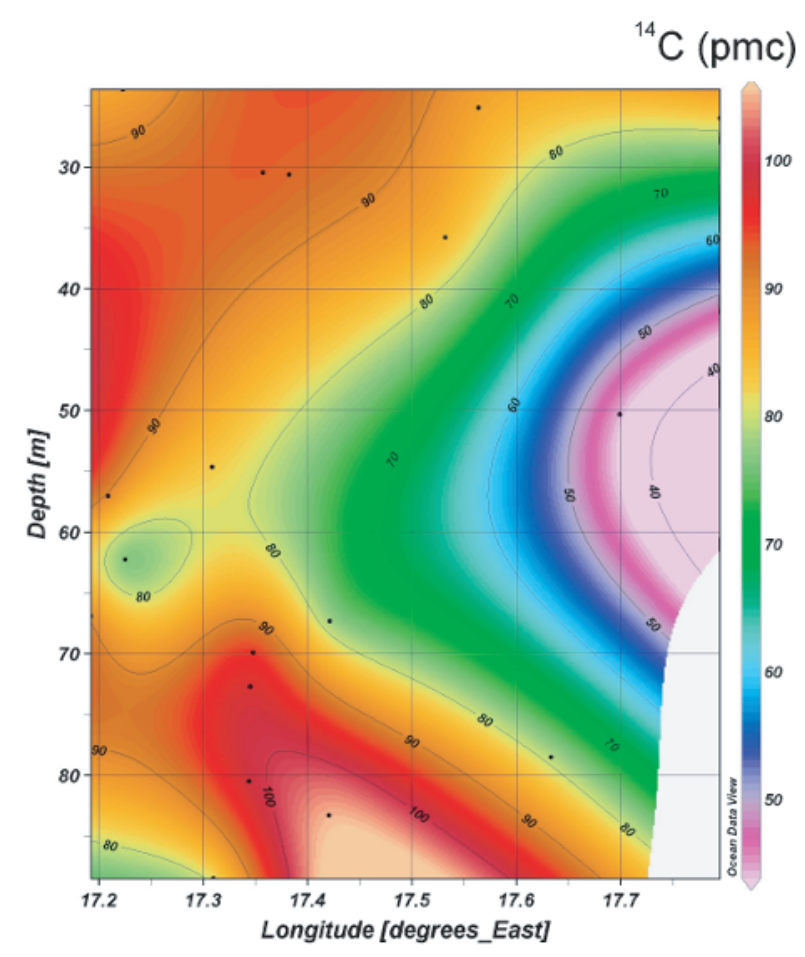

Fig. 5: Vertical distribution of ${ }^{14} \mathrm{C}$ (in pMC) with longitude in groundwater of Žitný ostrov.

More groundwater samples from the Žitný ostrov area will be collected and analysed during 2010 and 2011 expeditions, which will help to improve the spatial density of isotope data, and thus contribute to better understanding of the Žitný ostrov groundwater system. We hope that this new research approach will improve the capability and efficiency in using isotopic tools for deeper evaluation, more rigorous assessment and more efficient management of water resources in the region.

\section{Acknowledgement}

A part of this research was supported by the International Atomic Energy Agency (RC No. 14301), the EU Research \& Development Operational Program funded by the ERDF (project No. 26240220004), and the Slovak Scientific Grant Agency VEGA (grant No. 1/108/08). 


\section{References}

[1] Kendall C. and McDonnell J., Isotope Tracers in Catchment Hydrology (Elsevier, Amsterdam) 1999.

[2] Aggarwal P. K., Gat J. R. and Froehlich K. F. O. (Eds.), Isotopes in the Water Cycle (Springer, Heidelberg) 2006, 381 p.

[3] Ferronsky V. I. and Polyakov V. A., Environmental Isotopes in the Hydrosphere (Wiley, New York) 1982, 466 p.

[4] Aggarwal P., Froehlich K., Gonfiantini R. and Gat J., in Isotopes in the Water Cycle, and edited by AGGarwal P. K., GaT J. R. and Froehlich K. F. O. (Springer, Heidelberg) 2006, pp. 3-8.

[5] Bowen G. J., Wassenaar L. I. and Hobson K. A., Oecologia (2005), 10.1007/s00442-004-1813-y.

[6] Aggarwal P. K. and Araguás-Araguás L., IAEA CRP Report (2006).

[7] Michalko J., Slovak Geol. Mag., 5 (1999) 63.

[8] Franko O., Šivo A., Richtáriková M. and Povinec P. P. Acta Phys. Univ. Comen., 49 (2008) 125.

[9] Povinec P. P., Šivo A., Richtáriková M., Breier R., LúČan L'., Aggarwal P. K. and Araguás-Araguás L., Acta Phys. Univ. Comen., 51 (2010) 143.

[10] Povinec P. P., Franko O., Šivo A., Richtáriková M., Breier R., Aggarwal, P. K. and Araguás-Araguás L., Radiocarbon, 52 (2010) 1056.

[11] Epstein S. and Mayeda T., Geochim. Cosmochim. Acta, 4 (1953) 213.

[12] Povinec P., Radiochem. Radioanal. Letters, 9 (1972) 127.

[13] Povinec P., Nuclear Instruments and Methods, 156 (1978) 441.

[14] Usačev S., Povinec P., Chudý M. and Šeliga M., Radiocarbon, 15 (1973) 443. 